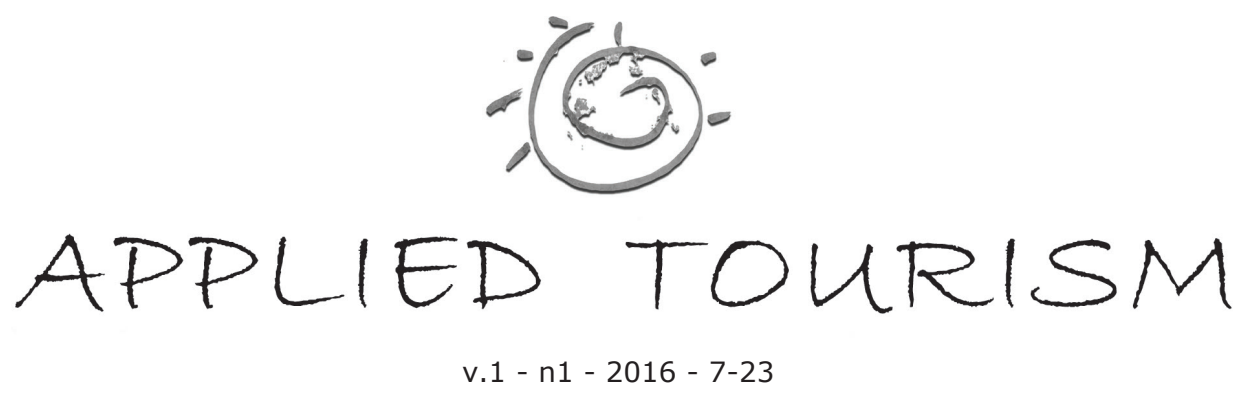

\title{
PLANEJAMENTO DE UMA TRILHA INTERPRETATIVA COMO FERRAMENTA DO ECOTURISMO NA APA DA BARRA DO RIO MAMANGUAPE - PARAÍBA, BRASIL
}

\section{PLANNING AN INTERPRETIVE TRAIL AS A TOOL FOR ECOTOURISM IN THE APA OF BARRA DO RIO MAMANGUAPE - PARAÍBA, BRAZIL}

\author{
Mércia Maria Araújo Luna - Mestranda em Ecologia e Monitoramento Ambiental - \\ Universidade Federal da Paraíba. E-mail: melluna.bio@gmail.com \\ Lucas Aguiar Nogueira Rosa - Graduando em Hotelaria - Universidade Federal da Paraíba. \\ E-mail: lucasaguiarnrosa@gmail.com \\ Vitor Pablo de Melo - Graduando em Ecologia - Universidade Federal da Paraíba. \\ E-mail: vitor.ecologia@hotmail.com
}

Recebido/Received: 22 outubro/october 2014. Aprovação/Approval: 18 janeiro/january 2015.

\begin{abstract}
Resumo: A Floresta Atlântica é um bioma biodiverso e extremamente impactado. A Área de Proteção Ambiental (APA) da Barra do Rio Mamanguape encontra-se inserida no hotspot da Floresta Atlântica. Este trabalho visa propor a implantação de uma trilha interpretativa na APA com base no Ecoturismo e na Educação Ambiental. Durante o mês de abril e maio de 2014 foi elaborado um roteiro mapeando os pontos estratégicos da trilha, elencando seus elementos mais representativos e registrandoos ao longo de $3.8 \mathrm{Km}$. Várias características da trilha foram consideradas na elaboração deste planejamento: a proteção do ambiente da trilha, seu potencial interpretativo, a acessibilidade e segurança. Os resultados
\end{abstract}

Abstract: The Atlantic Forest is an extremely biodiversity-rich and impacted biome. The Área de Proteção Ambiental - APA (Environmental Protection Area) of Barra do Rio Mamanguape is inserted in the Atlantic Forest Hotspot. This paper aims to propose the establishment of an interpretive trail on APA based on Ecotourism and Environmental Education. During the months of April and May 2014 a roadmap charting the strategic points of the trail was prepared, listing its most representative elements and recording them along $3.8 \mathrm{Km}$. Several features of the trail were considered in the preparation of this plan: the environmental protection of the trail, interpretative potential, accessibility and safety. The results showed 
apontaram nove pontos de atratividade onde foram abordados aspectos de relevância da flora, da fauna e da história da APA. Notase a necessidade da implantação de trilhas ecológicas no principal e maior fragmento de Floresta Atântica da APA, a Floresta do Oiteiro, uma vez que as trilhas só estão previstas no plano de manejo para um dos quatro municípios que abrange a APA, Lucena. Destaque pode ser dado à necessidade de treinamento de uma equipe local da Unidade de Conservação (UC) para manter vivo o instrumento da trilha interpretativa, associando a interlocução entre a comunidade acadêmica da UFPB e os turistas pelo seu caráter amplo e interdisciplinar.

Palavras-chave: Floresta Atlântica. Unidades de conservação. Turismo ecológico.

\section{INTRODUÇÃO}

As Unidades de Conservação (UCs) são áreas criadas pelo poder público ou privado com o objetivo de preservar e conservar a biodiversidade, os recursos naturais, assim como os processos ecológicos pertinentes aos ecossistemas naturais, além do patrimônio associado às manifestações culturais dos brasileiros. São essenciais na manutenção da diversidade biológica e dos serviços ecológicos (Oliveira, 2009)

De acordo com a Lei 9.985 de 2000, que define o Sistema Nacional de Unidade de Conservação (SNUC), as Áreas de Preservação Ambiental (APAs) são unidades de conservação para uso sustentável. Geralmente, é uma área extensa, com o objetivo de proteger a diversidade biótica e abiótica, ordenar o processo de ocupação humana e assegurar a sustentabilidade do uso dos recursos naturais. É constituída por terras públicas e privadas.

A APA da Barra do Rio Mamanguape encontra-se inserida no hotspot da Floresta Atlântica, apresenta altas taxas de endemismo e biodiversidade que estão ameaçados de extinção. Cabe ressaltar que a APA também está inserida dentro do contexto da Reserva da Biosfera da Floresta Atlântica - Fase VI, considerada a maior Reserva da Biosfera em área florestal do planeta, atendendo os requisitos estabelecidos pelo Programa Man and Biosphere $(\mathrm{MaB})$ para as Reservas da Biosfera, por sua importância à conservação da biodiversidade e para promoção do desenvolvimento sustentável (ICMBio, 2014).

O Decreto No 924, de 10 de setembro de 1993, que cria Área de Proteção Ambiental nine points of attractiveness where relevant aspects of the flora, fauna and history of the APA were addressed. The need to encourage and implement ecological trails in the main and largest part of the forest of APA, the Forest of Oiteiro, stood out since the trails are only provided in the management plan for one of the four municipalities covering the APA, Lucena. Emphasis should be given to the need for training the local staff of the Protected Area in order to keep alive the interpretive trail and, especially, to the opportunity of dialogue between the UFPB academic community and tourists fostered by the broad and interdisciplinary character of the trail.

Keywords: Atlantic Forest, protected area, ecological tourism

\section{INTRODUCTION}

Protected areas (UC in the Portuguese acronym) are areas established by public or private entities aiming to preserve the fauna, flora, water resources, soils, landscapes and ecological processes relevant to the ecosystems, as well as the heritage related to the Brazilian culture. The UCs are essential to the preservation of biological diversity, genetic stock represented by living organisms and in the maintenance of ecological services (Araújo, 2007; Oliveira, 2009).

According to the Law 9.985 2000, which defines the National System of Protected Areas (SNUC in the Portuguese acronym), the APA are protected areas for sustainable use. Generally, it is a large area with the goal of protecting biodiversity; regulate human activities and ensuring the sustainable use of natural resources. They comprise both public and private properties.

The APA of Barra do Rio Mamanguape is inserted in the Atlantic Forest Hotspot, which has a high rate of endemism and biodiversity that are threatened with extinction. It is worth noting that the APA is also part of the Atlantic Forest Biosphere Reserve - Phase VI, the largest biosphere reserve forest area in the world, meeting the requirements of the Man and Biosphere (MAB) Program for biosphere reserves due to their importance for biodiversity conservation and promotion of sustainable development (Instituto de Chico Mendes de Conservação da Biodiversidade, 2014).

The decree n. ${ }^{\circ} 924$ of September 10, 1993, establishing the Environmental Protection Area 
da Barra do Rio Mamanguape no Estado da Paraíba, especifica os seguintes objetivos de manejo para esta UC (ICMBio, 2014):

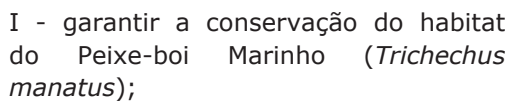

II - garantir a conservação de expressivos remanescentes de manguezal, Mata Atlântica e dos recursos hídricos ali existentes;

III - proteger o Peixe-boi Marinho (Trichechus manatus) e outras espécies, ameaçadas de extinção no âmbito regional);

IV - melhorar a qualidade de vida das populações residentes, mediante orientação e disciplina das atividades econômicas locais;

$\mathrm{V}$ - fomentar o turismo ecológico e a educação ambiental.

O ecoturismo é um movimento recente que tem chamado a atenção por sua relevância socioambiental, econômica. A prática do ecoturismo propicia a interpretação ambiental como uma tradução da linguagem da natureza para linguagem comum dos visitantes, auxiliando assim o desenvolvimento dos programas de educação ambiental nas áreas protegidas, aumentando a conscientização dos visitantes (Vasconcelos, 2003).

Dentre as estratégias utilizadas no Programa de Uso Público de Unidades de Conservação, as trilhas ecológicas se destacam pela naturalidade em que são transmitidos os conhecimentos relacionados a dinâmica da natureza. O objetivo é promover um contato mais estreito entre o homem e a natureza, constituindo-se em um instrumento pedagógico válido para a transformação de pensamentos, valores e atitudes. (Guillaumon, Poll \& Singy, 1977).

As trilhas interpretativas podem provocar nos participantes o sentimento de responsabilidade pela conservação do meio ambiente, a partir do reconhecimento do meio como um sistema integrado e dinâmico. (Vasconcellos, 2006). As trilhas podem ser classificadas em três categorias: a) quanto à função, que podem ser utilizadas para serviços administrativos, vigilância, atividades recreativas e educativas; b) quanto à forma, que podem ser circulares, em oito, linear e atalho; e c) quanto à presença ou não de um guia. (Filetto, 2003). Andrade (2003) ainda acrescenta uma categoria de classificação, of Barra do Rio Mamanguape, in the State of Paraíba, specifies the following management objectives for this UC (ICMBio, 2014):

I - Ensure the conservation of the habitat of Manatee Marine (Trichechus manatus);

II - Ensure the conservation of remaining mangrove expressive, Atlantic forest and water resources therein;

III - Protect the manatee (Trichechus manatus) and other species threatened with extinction at the regional level;

IV - Improve the quality of life for people living within the protected area through guidance and discipline of local economic activities;

V - Promote ecotourism and environmental education.

Ecological tourism is one of the fastest growing activities in the world, especially nature tourism, which is a specific branch of ecotourism (Trumbic, 2008). Molina (2001) reflects on the difficulty of having a successful tourist resort located in the banks of a polluted lake. Ecotourism is a recent movement that has drawn attention for its social, economic, cultural and environmental relevance.

Ecotourism provides an environmental interpretation, that is, a translation of nature into the common language of visitors, providing information instead of distraction and education in addition to fun. In this sense, the interpretation is acknowledge as a resource for the development of environmental education programs in protected areas, whose main purpose is to raise visitors' awareness of environmental issues (Vasconcellos, 2003).

Among the strategies listed in the Program for Public Use of Conservation Units, ecological trails stand out for their potential for in situ interpretation of nature, in which the flora, fauna and other natural phenomena are explained. The goal is to promote a closer contact between man and nature, thus promoting a shift of values and attitudes (Guillaumon, Poll \& Singy, 1977).

Interpretive trails may give rise to a sense of responsibility towards nature. Their main objective is to unfold environment's substance and features through the activities offered, using original elements, direct experiences and illustrative media such as billboards and informational signs (Vasconcelos, 2006). The trails can be classified into three categories, 
que é quanto ao grau de dificuldade, levando em consideração a topografia do terreno, a declividade, a duração, o percurso, a presença de obstáculos aleatórios, a intensidade da atividade e o nível técnico dos participantes. As trilhas também podem ser classificadas em guiadas e autoguiadas. (Mendes et al, 2007).

Este trabalho teve por objetivo planejar uma Trilha Interpretativa para a APA da Barra do Rio Mamanguape visando atender um dos objetivos propostos no Plano de Manejo da UC.

\section{MATERIAL E MÉTODOS}

\section{Área de Estudo}

A APA da Barra do Rio Mamanguape está localizada na microrregião do Litoral Norte da Paraíba, Brasil. Possui uma área de 14.640 ha, localizados em quatro municípios: Rio Tinto, Marcação, Baia da Traição e Lucena, entre as coordenadas geográficas $6^{\circ} 45^{\prime}$ a $6^{\circ} 50^{\prime} \mathrm{S}$ e $34^{\circ}$ $56^{\prime}$ a $35^{\circ} \mathrm{W}$. Esse apresenta um comprimento total de aproximadamente onze quilômetros (Figura 1) (Moura, 2011; ICMBio, 2014).

A pesquisa foi realizada em um dos últimos remanescentes de Floresta Atlântica do Estado da Paraíba. Ela é considerada uma floresta secundária, por estar em processo de regeneração referente às ações antrópicas. Com aproximadamente 235 ha, a Mata do Oiteiro é o maior fragmento da UC. (Pereira \& Alves, 2006).

\section{Método}

O presente estudo foi conduzido durante 0 mês de abril e maio de 2014, tendo como início das atividades o levantamento bibliográfico sobre ecoturismo e trilhas interpretativas e a análise do plano de manejo para obtenção de orientações para realização da pesquisa e da possibilidade de desenvolver uma trilha interpretativa na APA da Barra do Rio Mamanguape. Uma segunda metodologia aplicada à trilha foi baseada na técnica do IAPI desenvolvido por Magro e Freixêdas (1998). O método objetiva agregar ao potencial interpretativo de cada sítio selecionado, um valor qualitativo para aumentar a atratividade do local. Conforme a metodologia, desenvolvemos duas fases com o intuito de escolher pontos mais atrativos da trilha:

Fase 1 - Levantamento dos pontos potenciais para a interpretação: iniciou-se according to: a) function: administrative purposes, surveillance, recreational and educational activities; b) shape: circular, figure eight-shaped, straight or shortcut; and c) presence or absence of a guide field (Filetto, 2003). Andrade (2003) adds the degree of difficulty as another category of classification taking into account the topography, slope, length, route, the presence of random obstacles, the intensity of the activity and the participants' technical level. Trail can also be classified as guided and self-guided (Mendes et al., 2007).

When developing a trail it is important to consider the actual and local characteristics. Some aspects should be taken into consideration when designing an interpretive trail: the environmental protection of the trail, its interpretative potential, the accessibility and safety, its extent and the visitors' needs and demands (Projeto Doces Matas, 2002).

This study aimed to plan an Interpretive Trail for the APA of Barra do Rio Mamanguape to meet one of the objectives proposed in the management plan for that protected area.

\section{METHODOLOGY}

\section{Area under study}

The APA of Barra do Rio Mamanguape is located in the micro-region of North Coast of Paraíba, Brazil. It has an area of 14,640 ha distributed among four municipalities: Rio Tinto, Marcação, Baía da Traição e Lucena. It is located between the geographical coordinates $6^{\circ} 45^{\prime} 6^{\circ} 50^{\prime} \mathrm{S}$ and $34^{\circ} 56^{\prime} 35^{\circ} \mathrm{W}$. It has a total length of approximately eleven kilometers (Figure 1) (Moura, 2011; ICMBio, 2014).

The APA Barra do Rio Mamanguape belongs to the group of Conservation Sustainable Use, whose primary purpose is to strike a balance between environmental preservation and sustainable use of its natural resources (ICMBio, 2014).

Embedded in the hot and humid sector of the State (Carvalho, 1982), the climate of the region is type $A$, according to Köppen classification. It is characterized by a twomonth dry season and a rainy season between March and September. The average annual temperature is $28^{\circ} \mathrm{C}$ and annual precipitation ranges between 1200-1800 mm (Lima \& Heckendorff, 1985; ICMBio, 2014). 
- processo de interpretação da trilha com o exercício de observação e estudo de seus recursos naturais e culturais. Uma vez realizado o inventário do que havia de mais importante no local, escolhemos o tema a ser interpretado e iniciamos então, o processo de seleção dos pontos a serem apresentados aos visitantes.

Fase 2 - Levantamento e seleção de indicadores: iniciamos nesta fase um levantamento dos recursos naturais visíveis a partir dos pontos pré-selecionados na trilha para a escolha de alguns "indicadores de atratividade". A atratividade, segundo Magro e Freixêdas (1998), relaciona-se de maneira geral, com fatores naturais como variedade de vegetação, proximidade com corpos d'água, relevo, áreas históricas ou arqueológicas, entre outros. Vale ressaltar que o guia local, Adriano Felipe, foi fundamental para elencar em campo elementos de interesse da flora, fauna, dinâmica ambiental, aspectos sociais e culturais, de acordo com o seu repertório de conhecimentos tradicionais.

Após estas fases, a etapa seguinte consistiu no cálculo da extensão da trilha por GPS. A partir destas ações iniciais, uma nova etapa metodológica foi focada na construção de um mapa contemplando todos os pontos selecionados. Também é importante esclarecer que esta trilha foi realizada de forma experimental, uma vez que não houve a aplicação do método com turmas reais. Este trabalho foi realizado com a autorização do ICMBio (Solicitação SISBIO 50397).

\section{RESULTADOS E DISCUSSÃO}

A análise do plano de manejo nos levou a compreensão sobre as principais ameaças à APA: o Turismo predatório/desordenado; a Especulação imobiliária/empreendimentos hoteleiros; Carcinicultura/pesca predatória; Expansão da cultura canavieira/ desmatamento, e o Uso de madeira para subsistência. Direcionando o pensamento à problemática do turismo predatório/ desordenado foi constatado que o plano de manejo dá ênfase a iniciativas como atividades econômicas sustentáveis, ao turismo de conservação, entre outras estratégias que possam minimizar as ameaças.

Conforme exposto no Decreto N 0 924, (BRASIL, 1993), o quinto objetivo de manejo para a UC é formentar o turismo ecológico e a educação ambiental. Com o intuito de subsidiar a este objetivo, iniciamos um
This research was carried out in one of the last remnants of Northeastern Atlantic Forest in the State of Paraíba. It is considered a secondary forest, undergoing a regeneration process from human activity. With approximately 235 ha, the Forest of Oiteiro is the largest fragment of the UC (Pereira \& Alves, 2006).

Method

This study was done during the months of April and May 2014. Firstly, a literature review on ecotourism and interpretive trails was carried out. Also, an analysis of the management plan was done to obtain guidelines for planning the research and assess the possibility of developing a trail interpretation of the APA of Barra do Rio Mamanguape. Then a second methodology, based on Magro and Freixedas (1998) IAPI technique, was applied to the trail; the aim was adding a qualitative value to increase the attractiveness of each selected site,. A two-stage method was developed in order to choose the most attractive points of the trail:

Stage 1 - Survey of the potential points for interpretation: the process of interpretation of the trail started with the observation and study of its natural and cultural resources. Once listed the most important features of the site, the theme to be interpreted was chosen and the points to be presented to visitors were selected.

Stage 2 - Survey and selection of indicators: at this stage, the natural resources visible from the pre-selected points on the trail were analysed in order to choose some "indicators of attractiveness." The attractiveness according to Magro and Freixedas (1998) relates, in general, with natural factors such as variety of vegetation, proximity to water bodies, terrain, historical or archaeological sites, among others.

After these, the next step was calculating of the extension by GPS. It is noteworthy that a local guide was essential to outline, in situ, fauna, flora, environmental dynamics and social-cultural aspects, according to his repertoire of traditional knowledge.

Subsequently, a map displaying all selected points was made. It is also important to note that the trail was tried experimentally, since there was no application of the method to actual classes. 
processo de planejamento e elaboração de uma trilha interpretativa na Mata do Oiteiro, um dos últimos fragmentos de Floresta Atlântica do Litoral Norte da Paraíba.

Após a análise do plano de manejo e do resgate bibliográfico acerca do ecoturismo, educação ambiental e trilhas Interpretativas, selecionamos nove pontos de atratividade. A cada ponto elencamos questões introdutórias aos elementos de destaque da trilha, elementos estes relacionados ao contexto ambiental, social, histórico, cultural e econômico (Quadro 1).

O percurso proposto para a pratica da trilha interpretativa foi dividido em três setores: o primeiro setor corresponde ao trecho que se estende do início da trilha até o cultivo da cana-de-açúcar (pontos 1-5), o segundo, segue a partir da passagem pelo canavial, até o retorno a Mata do Oiteiro (pontos 6-7; Figura $6)$, o último trecho tem inicio no retorno da Mata do Oiteiro e se prolonga até a Praia do Oiteiro (pontos 7 - 9).

A Trilha, objeto deste estudo, é do tipo atalho, onde seu início e fim estão em diferentes pontos (Figura 2). A trilha é também do tipo guiada (que requer a presença de um intérprete ou guia) do tipo natural temática, em que o intérprete seleciona os pontos de paradas com antecedência, resultando em maior coerência à atividade. A trilha é classificada como moderada em relação ao grau de dificuldade. (Campos \& Ferreira, 2006). Apresenta extensão total de aproximadamente $3,8 \mathrm{Km}$ com uma média de duas horas de caminhada incluindo as paradas interpretativas, podendo ser feita por estudantes, turistas e moradores locais. Ao logo do percurso a trilha apresenta pouca variação em relação a sua largura, com exceção do ponto de passagem entre a borda do fragmento e do plantio de cana-de-açúcar.

DESCRIÇÃO DOS SETORES DA TRILHA

\section{Primeiro setor}

Neste setor observa-se a diversidade florística da Mata do Oiteiro, predominando principalmente espécies de estrato arbóreo e arbustivo. Podem ser observados ambientes com árvores que formam bosques de até $5 \mathrm{~m}$ de altura, com alguns exemplares emergentes que chegam a atingir até $10 \mathrm{~m}$

\section{RESULTS AND DISCUSSION}

The analysis of the Management Plan allowed us to understand the main threats that the APA is facing: predatory and uncontrolled tourism; real estate speculation / hotel developments; shrimp farming / overfishing; expansion of sugarcane / deforestation and exploitation of wood for subsistence use. The Management Plan emphasizes initiatives such as sustainable economic activities, tourism and conservation, among other strategies to minimize threats and particularly to address the predatory and uncontrolled tourism.

As stated in Decree No. 924 of September 10,1993 , the fifth goal of management for the protected area is to promote ecotourism and environmental education. To this purpose, we initiated a planning process and development of an interpretive trail on the Oiteiro Forest, one of the last fragments of Atlantic Rainforest in the North Coast of Paraíba.

After the analysis of the Management Plan, the information collected from the local guide and the literature review on ecotourism, environmental education and interpretive trails, the nine points of attractions were selected. At each point we listed the introductory questions related to the environmental, social, historical, cultural and economic highlights of the trail (Table 1 ).

The proposed route for the practice of interpretive trail has been divided into three sectors: the first sector extends from the beginning of the trail to the sugar cane plantations (points 1-5), the second goes from the cropland to the Oiteiro Forest (points 6-7; Figure 6) and the last part extends from there to the Oiteiro beach (points 7-9).

The trail, object of this study is of a shortcut type, that is, the start and end points are different (Figure 2). It is a natural-themed and guided type of trail (it requires the presence of an interpreter or guide) in which the interpreter selects the points charts in advance thus conferring a great consistency to the activity. Regarding the degree of difficulty, this trail is rated moderate (Fields \& Ferreira, 2006). It has a total length of approximately $3.8 \mathrm{~km}$ and it takes an average of two hours to complete, including the interpretive stops, and can be done by students, tourists and locals. The trail width does not vary much, except for the crossing point between the edge of the fragment and the sugar cane plantation. 
de altura. Na cobertura vegetal desse fragmento também há a ocorrência de várias espécies de lianas e trepadeiras. (Pereira \& Alves, 2006; ICMBio, 2014).

Além da apresentação das características principais desta floresta secundária, a primeira parada serve como uma introdução a problemática do desmatamento na região, o que influência direta e indiretamente na perda da biodiversidade, um dos motivos pode ser a fragmentação dos habitats (Primack \& Rodrigues, 2001).

No ponto subsequente destaca-se a Elaeis guineensis (dendezeiro, dendê, palma-deguiné, entre outros nomes populares), que é uma palmeira (Arecaceae) de origem africana (Leão et al., 2011), cujos frutos costumam ser extraídos por mamíferos de pequeno e médio porte. A comunidade local gera dois tipos de óleos como matéria prima: o óleo da polpa e o óleo da amêndoa, também chamado de azeite de dendê. Neste trecho além de ressaltar as vantagens do dendê, pretende indagar os visitantes a respeito de questões relacionadas à dinâmica da flora nativa em detrimento das espécies invasoras.

O Ponto 3 é marcado pela Spondias mombin (cajá, cajarana, cajazeira) uma árvore nativa da mesma família do cajueiro, Anarcadiaceae, com distribuição ampla entre o Norte e sudeste do Brasil, com ocorrência nos biomas Amazônia, Cerrado, Caatinga e Floresta Atlântica (Silva-Luz \& Pirani, 2014). Apresenta forma de vida árborea, chegando a atingir até 25 metros. No período de frutificação, esta serve como fonte econômica para a população local.

Outras espécies nativas como a mangabeira e o cajueiro (Hancornia speciosa Gomez e Anarcadium occidentale, respectivamente) são facilmente visualizadas ao longo do primeiro setor, revelando uma diversidade botânica de relevante interesse econômico. Estas são espécies típicas dos tabuleiros costeiros nordestinos.

O estudo de Pereira e Alves (2006) registrou na Mata do Oiteiro um total de 111 espécies, distribuídas em 92 gêneros, integrantes de 44 famílias. Em relação à distribuição do número de espécies por famílias, evidenciou-se que as cinco mais diversas foram respectivamente: Rubiaceae com 16 espécies, Fabacea com 12 e Anacardiaceae, Boraginaceae e Euphorbiaceae com 5 espécies cada (ICMBio, 2014).

Apesar da diversidade, algumas espécies encontram-se ameaçadas de extinção.

\section{DESCRIPTION OF THE SECTORS OF} THE TRAIL

\author{
First sector
}

In this sector, the diversity flora of the Oiteiro Forest can be observed, especially the predominant tree species and shrub layer. Environments with trees forming groves of up to $5 \mathrm{~m}$ high, with some emerging examples that reach up to $10 \mathrm{~m}$ in height can also be observed. Vegetation cover in this fragment includes several species of lianas and vines (Pereira \& Alves, 2006; ICMBio, 2014).

Besides the presentation of the main characteristics of this secondary forest, the first stop serves as an introduction to the problem of deforestation in the region, which leads, directly and indirectly, to biodiversity loss; one reason may be the fragmentation of habitats (Primack \& Rodrigues, 2001).

In the next stop the Elaeis guineensis (dendezeiro, dendê, palma-de-guiné, among other popular names) stands out; it is a palm tree (Arecaceae) of African origin (Leo Almeida, Dechoum \& Ziller, 2011), whose fruits are usually extracted by small and medium mammalian. The local community produces two types of oils as a raw material: the pulp oil and almond oil, also called palm oil. At this point, the advantages of palm oil should be underlined and visitors are to be questioned about issues related to the dynamics of native flora at the expense of invasive species.

The third point is marked by Spondias mombin L. (cajá, ajarana, cajazeira), a native tree of the same family as the cashew tree, Anarcadiaceae, with wide distribution across North and Southeast of Brazil, occurring in Amazon, Cerrado, Caatinga and Atlantic Forest biomes (Silva Luz, CL \& Pirani, 2014). It shows how arboreal life can reach up to 25 meters. In the fruiting period, it is an economic resource for the local population.

Other native species, such as the mangabeira and the cashew tree (Hancornia speciosa and Anacardium occidentale respectively) are easily spotted in the first sector, revealing a significant botanical diversity and of economic relevance. These species are typical of the Northeast Coastal Tablelands (ICMBio, 2014).

The study of Alves and Pereira (2006) recorded in the Forest Oiteiro a total of 111 species, distributed in 92 genera, members 
Vale salientar que o aspecto estrutural da vegetação evidencia a influência da ação antrópica, principalmente pela escassez de grandes faixas contínuas da cobertura vegetal.

No final do primeiro setor, a trilha chega a uma vegetação de maior porte arbóreo, em virtude de um curso d'água, chamado Riacho Caracabú (Figura 3). O Riacho dá certo talento à atratividade deste ponto por estar regado na potencialidade dinâmica do ambiente, contribuindo como recurso hídrico para a biota e para a manutenção do microclima.

Plantas características de remanescentes de Floresta Atlântica são comumentes encontradas ao longo do percurso da trilha: Bowdichia virgilioides (sucupira), Byrsonima sericea (murici), Scheffler, Ocotea duckei (louro), Pogonophora schomburgkiana (cocão), Protium heptaphyllum Marchand e Tapirira guianensis (cupiúba) (ICMBio, 2014).

A cupiúba (Figura 4) é uma espécie arbórea nativa que marca o último ponto (ponto 5) do setor. Ela tem uma distribuição ampla no Brasil, abrangendo a Amazônia, a Caatinga, o Cerrado, o Pampa e o Pantanal (Forzza et al., 2014). A seiva da cupiúba serve de alimento para uma espécie de primata, o Callithrix jacchus, popularmente conhecido como sagui.

\section{Segundo Setor}

O segundo setor se inicia no ponto 6 , onde se planeja abordar os principais impactos decorrentes da monocultura de cana-deaçúcar (Figura 5): contaminação do solo e o efeito de borda desencadeia alguns processos, como o aumento nas temperaturas, diminuição da umidade, perda da biota, alterações na paisagem, entre outros efeitos prejudiciais ao ambiente (Primack \& Rodrigues, 2001).

$\mathrm{Na}$ Paraíba, a destruição da Floresta Atlântica acontece principalmente para dar lugar as plantações de cana-de-açúcar e a exploração madeireira, reduzindo o bioma a pequenos fragmentos (Barbosa, 1996). Na área da APA não é diferente, os impactos ambientais são decorrentes direta ou indiretamente da agricultura canavieira, afetando os tabuleiros e encostas e o ecótono Savana/Restinga (MMA/ PNMA, 1998; ICMBio, 2014).

Terceiro Setor

Espécies arbóreas nativas de destaque na mata, a Tabebuia sp. (ipê amarelo - of 44 families. Regarding the distribution of the number of species per family, it is evident that the ten most numerous were: Rubiaceae (16), Fabaceae (12), Anacardiaceae (05), Boraginaceae (05), Euphorbiaceae (05), Sapindaceae (04), Annonaceae (03), Bignoniaceae (03), Caesalpiniaceae (03), Chrysobalanaceae (03) (ICMBio, 2014).

Despite the diversity, the structural aspect of the vegetation shows the influence of anthropogenic activities, mainly by the shortage of large continuous strips of vegetation cover. The size of trees and shrubs can also change depending on the soil depth and the presence of water bodies.

At the end of the first sector, the trail reaches larger arboreal vegetation, due to a watercourse, a creek called Caracabú (Figure 3 ). The creek is not only an attractive feature of the trail but it also plays an important role in the environmental dynamics, contributing to water resource for the biota and the maintenance of the microclimate.

Characteristic plants of the Atlantic Forest remnants are commonly found along the route of the trail: Bowdichia virgilioides Humb, Bompl. \& Kunth (sucupira) Byrsonima sericea DC. (murici), Scheffler, Ocotea duckei Vattimo (blonde), Pogonophora schomburgkiana Miers (cocão), Protium heptaphyllum (Aubl.) Marchand and Tapirira guianensis Aubl. (cupiúba) (ICMBio, 2014).

The cupiúba (Figure 4) is a native tree species that marks the last point of this sector (point 5). It has a wide distribution in Brazil, including the Amazon, Caatinga, Cerrado, the Pantanal and Pampa (Forzza et al., 2014). The sap of cupiúba serves as food for a species of primate, Callithrix jacchus, popularly known as marmosets.

\section{Second Sector}

The second sector starts at point 6 ; there the consequences of sugarcane monoculture will be addressed (Figure 5): contamination of soil and the edge effect which triggers some processes, such as increased temperatures, decreased humidity loss of biota, changes in the landscape, among other environmentally harmful effects (Primack \& Rodrigues, 2001).

In Paraíba, the destruction of the Atlantic Forest is especially due to the sugarcane bagasse and logging, reducing the biome to small fragments (Barbosa, 1996). It 
Bignoniaceae), e do tabuleiro, a Curatella americana (cajueiro bravo, lixeira Dilleniaceae), são encontrados após a passagem pelo canavial (ponto 7 e 8; figura 7 e 8). Ambas as espécies ocorrem do norte ao sul do país.

A última parada a ser visitada (ponto 9; Figura 9), trata-se da praia do Oiteiro que representa um grande potencial atrativo por sua beleza natural e turismo de "praia e sol", assim como o turismo de surfe. Nesta parada pretendemos sintetizar os aspectos mais importantes que foram explorados ao longo da trilha, buscando sensibilizar e conscientizar os visitantes a respeito da importância do turismo ecológico nas UCs para a proteção e manutenção dos ecossistemas costeiros e terrestres.

A Mata do Oiteiro é um dos mais importantes fragmentos setentrionais costeiros da Floresta Atlântica. (Rosa \& Sassi, 2002). Apesar deste fragmento se encontrar isolado de outros e ser recortado por diversas trilhas indicando forte pressão humana, a fauna de mamíferos e répteis da Mata do Oiteiro apresenta um número maior na APA, por estes motivos, este fragmento é considerado a área mais prioritária para conservação (Sugliano, 2002; Giminez,2002; ICMBIo, 2014).

\section{CONCLUSÃO}

A APA da Barra do Rio Mamanguape tem um grande potencial para o desenvolvimento de turismo em base comunitária, ecoturismo, e atividades diversas de educação ambiental. De acordo com o plano de manejo, as atividades como trilhas ecológicas só estão previstas para o município de Lucena. No entanto é no município de Rio Tinto que se encontra a Mata do Oiteiro, o maior fragmento de floresta secundária da APA, com pontos atrativos diversos, que acreditamos oferecer um maior potencial para o ecoturismo.

Iniciativas de criação de trilhas interpretativas em UCs de uso sustentável, de fato, contribuem para a utilização dos ambientes naturais de forma sustentável quando bem planejadas e executadas. A trilha sugerida tem grande potencial de interpretação. Por ser uma trilha já utilizada principalmente pela comunidade local, torna-se fácil implantá-la como ferramenta para prática do ecoturismo, podendo contribuir como reforço na renda da comunidade, quando esta participar happens the same in the area of the APA; the environmental impacts are directly or indirectly related to sugarcane production, affecting the tablelands and slopes and the ecotone Savana/Restinga (MMA / NEP, 1998; ICMBio, 2014).

\section{Third Sector}

Native tree species in the forest, Tabebuia $s p$. (ipê-amarelo-Bignoniaceae), and in the tableland, Curatella americana (cajeueirobravo, lixeira - Dilleniaceae), are found after passing through the sugarcane field (Point 7 and 8; Figure 7: and 8). Both species are distributed from the north to the south of the country.

The last stop of the trail (Point 9; Figure 9) is the Oiteiro beach which is a great attraction for its natural beauty and "sand and sun" tourism potential. At this stop we aim to summarize the most important aspects that were explored along the trail, trying to raise visitors' awareness about the importance of ecotourism in protected areas so as to preserve coastal and terrestrial ecosystems.

The Oiteiro Forest is one of the most important coastal northern fragments of Rainforest biome (Rose \& Sassi, 2002). Although this fragment was found to be isolated from others and cut several tracks indicating strong human pressure, the fauna of mammals and reptiles of the Oiteiro Forest is still abundant in the APA, and so this fragment is considered of highest priority for conservation (Sugliano, 2002; Giminez, 2002; ICMBio, 2014).

\section{CONCLUSION}

The APA of Barra do Rio Mamanguape has great potential for developing communitybased tourism, ecotourism, and various environmental education activities. According to the management plan, activities like nature trails are only available in the city of Lucena. However, it is in the municipality of Rio Tinto that the largest fragment of the APA secondary forest is located. The Oiteiro Forest possesses many attractive points that we believe offer the greatest potential for ecotourism.

Initiatives to create interpretive trails in protected areas of sustainable use, in fact, if well planned and executed, with the direct participation of the academic and local 
diretamente das atividades junto aos turistas e da comunidade acadêmica.

\section{AGRADECIMENTOS}

Agradecemos a Adriano Felipe por nos guiar na trilha da Mata do Oiteiro, e a Hugo Yuri Assis pela elaboração do mapa de localização.

\section{REFERÊNCIAS}

Andrade, W. J. (2003). Implantação e manejo de trilhas. In: MITRUAD, S. (org). Manual de ecoturismo de base comunitária: ferramentas para um planejamento responsável. WWF Brasil: Brasília.

Assis, H. Y. E. G. (2014). Análise das classes de paisagem da APA da Barra do Rio Mamanguape - $P B$. Trabalho de Conclusão de Curso; Universidade Federal de Paraíba, Campus IV, Rio Tinto.

Campos, A. M. N. Ferreira, E. A. (2006). A trilha interpretativa da Vila do americano - PA, Brasil: Uma busca por conservação ambiental. Turismo em análise, (Vol. 17, pp. 155 - 169).

Brasil. Decreto n. 924, de 10 de setembro de 1993 (1993). Dispõe sobre a criação da Área de Proteção Ambiental da Barra do Rio Mamanguape, entidade federal de implementação do Sistema Nacional de Unidades de Conservação dá outras providências. Brasília. 200. Retrieved October 28, 2014, from htttp://www. ibama.gov.br

Filetto, F. (2003). Conservação ambiental de trilhas ecoturísticas de interpretação da natureza. In: Seminário Nacional de Degradação e Recuperação Ambiental, Anais. Foz do Iguaçú, PR.

Forzza, R. C. Costa, A. Walter, B. M. T. Pirani, J. R. Morim, M. P. Queiroz, L.P. (2014). Angiospermas in Lista de Espécies da Flora do Brasil. Retrieved November 05, 2014, from http://reflora.jbrj.gov. br/jabot/listaBrasil/ConsultaPublicaUC/ ConsultaPublicaUC.

Guillaumon, J. R. Poll, E.; Singy, J. M. (1977). Análise das trilhas de interpretação. São Paulo: Instituto Florestal, (Bol. Técn. IF, 25). (p. 57).

ICMBio - Instituto Chico Mendes de Conservação da Biodiversidade. (2014). Plano de Manejo da Apa da Barra do Rio Mamanguape. Brasília.

Leão, T. C. C. almeida, W. R. Dechoum, M. S. e Ziller, S. R. (2011). Espécies Exóticas Invasoras no Nordeste do Brasil: communities, may contribute to a sustainable use of natural environments.

The trail has revealed a great potential for interpretation. Being a track already used, mainly by the local community, it is easy to deploy it as a tool for ecotourism, which may contribute to enhancing the income of the community, when it participates directly in the tourist activities.

The planning of interpretive trail on the Oiteiro Forest was based on the principles of ecotourism, aiming to develop visitors' critical sense towards the importance of conserving the environment.

\section{REFERENCES}

Andrade, W. J. (2003). Implantação e manejo de trilhas. In: MITRUAD, S. (org). Manual de ecoturismo de base comunitária: ferramentas para um planejamento responsável. WWF Brasil: Brasília.

Araújo, M. A. R. (2007). Unidades de conservação no Brasil: da república à gestão de classe mundial. Belo Horizonte: Segrac, 6 cap.

Assis, H. Y. E. G. (2014). Análise das classes de paisagem da APA da Barra do Rio Mamanguape - $P B$. Trabalho de Conclusão de Curso; Universidade Federal de Paraíba, Campus IV, Rio Tinto.

Campos, A. M. N. Ferreira, E. A. (2006). A trilha interpretativa da Vila do americano - PA, Brasil: Uma busca por conservação ambiental. Turismo em análise, (Vol. 17, pp. 155 - 169).

Campos, A. M. N.; Ferreira, A. E. (2006). Trilha Interpretativa: busca por conservação ambiental. Caderno Virtual de Turismo ISSN: $1677-6976$ V. 6

Carvalho, M. G. R. F. (1982). Estado da Paraíba: classificação geomorgológica. João Pessoa. Editora Universitária, UFPB/ FUNAPE, (p.72).

Decreto n. 924, de 10 de setembro de 1993 (1993). Dispõe sobre a criação da Área de Proteção Ambiental da Barra do Rio Mamanguape, entidade federal de implementação do Sistema Nacional de Unidades de Conservação dá outras providências. Brasília. 200. Retrieved October 28, 2014, from htttp://www. ibama.gov.br

Filetto, F. (2003). Conservação ambiental de trilhas ecoturísticas de interpretação da natureza. In: Seminário Nacional de Degradação e Recuperação Ambiental, Anais. Foz do Iguaçú, PR. 
Contextualização, Manejo e Políticas Públicas. CEPAN, Instituto Hórus. Recife.

MMA - Ministério do Meio Ambiente/PNMA - Programa Nacional de Meio Ambiente (1998). Caracterização dos ativos ambientais em áreas selecionadas da Zona Costeira Brasileira. Brasília, 136p.

Magro, T. C.; Freixêdas, V. M. (1998), Trilhas: Como facilitar a seleção de pontos interpretativos. Departamento de Ciências Florestais, Circular Técnica. IPEF. ESALQ/ USP, N. 186, (pp. 4-10).

Mendes, A. F. Souza, S. A. de, Tabanez, M. F. (2007). A Trilha Interpretativa das Árvores Gigantes do Parque Estadual de Porto Ferreira na modalidade autoguiada. Rev. Inst. Flor., São Paulo, v. 19, n. 2, p. 173188 ,

Moura, L. (2011). Influência da Geomorfologia na Fisionomia da Vegetação no litoral de Rio Tinto - PB. X Congresso de Ecologia do Brasil. Retrieved November, 05, 2014, from http://www.seb-ecologia.org.br/ xceb/resumos/1461.pdf

Oliveira, L. R. N. de, (2009). Unidades de conservação da natureza. São Paulo, 3 n. Cadernos de Educação Ambiental. Governo do Estado de São Paulo: Secretaria do Meio Ambiente: Fundação Florestal,

Pereira, M. S. Alves, R. R. N. (2006). Composição Florística de um remanescente de Mata Atlântica na Área de Proteção Ambiental Barra do Rio Mamanguape, Paraíba, Brasil. Revista de Biologia e Ciências da Terra. V. 6 - Número 1 - 20 Semestre.

Primack, R, B. Rodrigues, E. (2001). Ameaça à diversidade biológica. (Ed. Planta). Fragmentação do habitat. (Vol.1).

Rosa, R. S. \& Sassi, R. (2002). Estudo da biodiversidade da Área de Proteção Ambiental barra do Rio Mamanguape. João Pessoa: PRODEMA - Universidade Federal da Paraíba. Relatório Técnico Final. CNPq. $371 p$.

Silva-Luz, C. L. Pirani, J. R. Anacardiaceae in Lista de Espécies da Flora do Brasil. Jardim Botânico do Rio de Janeiro. Retrieved November, 02, 2014: <http://floradobrasil. jbrj.gov.br/jabot/floradobrasil/FB4404>

Sugliano, G. O. S. (2002). Diversidade dos Répteis. In: Estudo da Biodiversidade da Área de Proteção Ambiental da Barra do Rio Mamanguape. ROSA, R. S.; SASSI, R. (Org.). João Pessoa: DSE/DGEOC/PPGCB/ PRODEMA/UFPB. 371pp.

Vasconcelos, J. M. O. (2003). Interpretação ambiental. IN: MITRUAD, S. (org). Manual de ecoturismo de base comunitária: ferramentas para um planejamento responsável. Brasília: WWF Brasil.

Vasconcellos, J. M. O. (2006). Educação e
Forzza, R. C. Costa, A. Walter, B. M. T. Pirani, J. R. Morim, M. P. Queiroz, L.P. (2014). Angiospermas in Lista de Espécies da Flora do Brasil. Retrieved November 05, 2014, from http://reflora.jbrj.gov. br/jabot/listaBrasil/ConsultaPublicaUC/ ConsultaPublicaUC.do

Gimenez, E. A. (2002). Diversidade de Mamíferos. In: Estudo da Biodiversidade da Área de Proteção Ambiental da Barra do Rio Mamanguape. ROSA, R. S. Sassi, R. (Org.). João Pessoa: DSE/DGEOC/PPGCB/ PRODEMA/UFPB. (p. 371).

Guillaumon, J. R. Poll, E.; Singy, J. M. (1977). Análise das trilhas de interpretação. São Paulo: Instituto Florestal, (Bol. Técn. IF, 25). (p. 57).

Instituto Chico Mendes de Conservação da Biodiversidade (ICMBio). Plano de Manejo (2014). Brasília.

Jardim Botânico do Rio de Janeiro. Retrieved November 02, 2014, from <http://floradobrasil.jbrj.gov.br/jabot/ floradobrasil/FB128482>

Leão, T. C. C. almeida, W. R. Dechoum, M. S. e Ziller, S. R. (2011). Espécies Exóticas Invasoras no Nordeste do Brasil: Contextualização, Manejo e Políticas Públicas. CEPAN, Instituto Hórus. Recife.

Lima, P. J. \& Heckendorff, W. D. (1985). Climatologia. In: Paraíba, Secretaria da Educação e Universidade Federal da Paraíba. Atlas Geográfico do Estado da Paraíba. (pp. 34-43). João Pessoa: Grafset. (pp. 34-43).

MMA - Ministério do Meio Ambiente/PNMA - Programa Nacional de Meio Ambiente (1998). Caracterização dos ativos ambientais em áreas selecionadas da Zona Costeira Brasileira. Brasília, 136p.

Magro, T. C.; Freoxêdas, V. M. (1998), Trilhas: Como facilitar a seleção de pontos interpretativos. Departamento de Ciências Florestais, Circular Técnica. IPEF. ESALQ/ USP, N. 186, (pp. 4-10).

Mendes, A. F. Souza, S. A. de, Tabanez, M. F. (2007). A Trilha Interpretativa das Árvores Gigantes do Parque Estadual de Porto Ferreira na modalidade autoguiada. Rev. Inst. Flor., São Paulo, v. 19, n. 2, p. 173188,

Molina, E. S. (2001). Turismo e ecologia. Bauru, São Paulo. EDUCS.

Moura, L. (2011). Influência da Geomorfologia na Fisionomia da Vegetação no litoral de Rio Tinto - PB. X Congresso de Ecologia do Brasil. Retrieved November, 05, 2014 from http://www.seb-ecologia.org.br/ xceb/resumos/1461.pdf

Oliveira, L. R. N. de, (2009). Unidades de conservação da natureza. São Paulo, 3 n. Cadernos de Educação Ambiental. Governo 
Interpretação Ambiental em Unidades de Conservação. Curitiba, Fundação $\mathrm{O}$ Boticário de Proteção à Natureza. Cadernos de Conservação ano 3, n. 4, dez. 2006. do Estado de São Paulo: Secretaria do Meio Ambiente: Fundação Florestal,

Pereira, M. S. Alves, R. R. N. (2006). Composição Florística de um remanescente de Mata Atlântica na Área de Proteção Ambiental Barra do Rio Mamanguape, Paraíba, Brasil. Revista de Biologia e Ciências da Terra. V. 6 - Número 1 - 20 Semestre.

PDM - Projeto Doces Matas (2002). Grupo Temático de Interpretação Ambiental. Manual de introdução à interpretação ambiental. Belo Horizonte,

Primack, R, B. Rodrigues, E. (2001). Ameaça à diversidade biológica. (Ed. Planta). Fragmentação do habitat. (Vol.1).

Rosa, R. S. \& Sassi, R. (2002). Estudo da biodiversidade da Área de Proteção Ambiental barra do Rio Mamanguape. João Pessoa: PRODEMA - Universidade Federal da Paraíba. Relatório Técnico Final. CNPq. $371 \mathrm{p}$.

Silva-Luz, C. L. Pirani, J. R. Anacardiaceae in Lista de Espécies da Flora do Brasil. Jardim Botânico do Rio de Janeiro. Retrieved November, 02, 2014: <http://floradobrasil. jbrj.gov.br/jabot/floradobrasil/FB4404>

Rosa, R. S. \& Sassi, R. (2002). Estudo da biodiversidade da Área de Proteção Ambiental barra do Rio Mamanguape. João Pessoa: PRODEMA - Universidade Federal da Paraíba. Relatório Técnico Final. CNPq. $371 \mathrm{p}$.

Sugliano, G. O. S. (2002). Diversidade dos Répteis. In: Estudo da Biodiversidade da Área de Proteção Ambiental da Barra do Rio Mamanguape. ROSA, R. S.; SASSI, R. (Org.). João Pessoa: DSE/DGEOC/PPGCB/ PRODEMA/UFPB. 371pp.

Trumbic, I. (1999) Sustainable tourism in coastal areas and islands: Opportunities, challenges and policies, In: Conselho da Europa. Links between the sustainable development of touism and regional/ spatial planning. Palma de Majorca: Council of Europe Publishing, p.50-61. Retrieved Maio, 03, 2014 from http://www. globalgarbage.org/turismo/Do_turismo_ predatorio_ao_turismo_sustentavel uma_revisao_sobre_a_origem_e_a_ consolidacao_do_discurs.pdf>

Vasconcellos, J. M. O. (2003). Interpretação ambiental. IN: MITRUAD, S. (org). Manual de ecoturismo de base comunitária: ferramentas para um planejamento responsável. Brasília: WWF Brasil.

Vasconcellos, J. M. O. (2006). Educação e Interpretação Ambiental em Unidades de Conservação. Curitiba, Fundação O Boticário de Proteção à Natureza. Cadernos de Conservação ano 3, n. 4, dez. 2006. 


\section{Attachments}

Quadro 1. Pontos de atratividades e suas respectivas abordagens.

\begin{tabular}{|c|c|c|c|}
\hline \multicolumn{2}{|c|}{ Pontos da Trilha } & \multirow{2}{*}{\begin{tabular}{|c|} 
Aspectos a serem abordados \\
Apresentar as recomendações necessárias para fazer a trilha como: \\
manter o silêncio, ter cuidado ao manipular os alimentos, não alimentar \\
os animais, não coletar nenhuma planta e/ou sua inflorescência, \\
não alterar a biotal; não fazer algazarras; incentivar a observação e \\
interpretação ambiental.
\end{tabular}} & \multirow{2}{*}{\begin{tabular}{|} 
Coordenadas \\
$6^{\circ} 49^{\prime} 55.4^{\prime \prime} \mathrm{S}$ \\
$34^{\circ} 54^{\prime} 46.3^{\prime \prime} \mathrm{O}$
\end{tabular}} \\
\hline Ponto 1 & Início da Trilha & & \\
\hline Ponto 2 & $\begin{array}{l}\text { Dendezeiro - Elaeis } \\
\text { guineensis (espécie } \\
\quad \text { invasora) }\end{array}$ & $\begin{array}{c}\text { Apresentar as espécies nativas e oportunistas predominantes no percurso } \\
\text { da trilha, identificando sua importância e a problemática das espécies } \\
\text { invasoras. }\end{array}$ & $\begin{array}{l}6^{\circ} 49^{\prime} 55.9^{\prime \prime} \mathrm{S} \\
34^{\circ} 54^{\prime \prime} 50.7^{\prime \prime} \mathrm{O}\end{array}$ \\
\hline Ponto 3 & $\begin{array}{l}\text { Cajá - Spondias } \\
\text { mombin }\end{array}$ & $\begin{array}{l}\text { Falar sobre as características e peculiaridades da espécie, assim como } \\
\text { sua importância econômica e cultural. }\end{array}$ & $\begin{array}{l}6^{\circ} 49^{\prime} 56.0^{\prime \prime S} \\
34^{\circ} 55^{\prime} 00.3^{\prime \prime} \mathrm{O}\end{array}$ \\
\hline Ponto 4 & Riacho Caracabú & Abordar sobre a importância ecológica dos corpos aquáticos. & $\begin{array}{l}6^{\circ} 49^{\prime} 56.1^{\prime \prime} \mathrm{S} \\
34^{\circ} 55^{\prime} 01.9^{\prime \prime} \mathrm{O}\end{array}$ \\
\hline Ponto 5 & $\begin{array}{l}\text { Cupiúba - Tapirira } \\
\text { guianensis }\end{array}$ & $\begin{array}{l}\text { Falar sobre as características e peculiaridades da espécie, assim como } \\
\text { sua importância ecológica. }\end{array}$ & $\begin{array}{l}6^{\circ} 49^{\prime} 52.2^{\prime \prime} \mathrm{S} \\
34^{\circ} 55^{\prime} 16.9^{\prime \prime} \mathrm{O}\end{array}$ \\
\hline Ponto 6 & Trecho no Canavial & $\begin{array}{l}\text { Alertar sobre os impactos decorrentes do cultivo de cana-de-açúcar } \\
\qquad \text { (clima e biota). }\end{array}$ & $\begin{array}{l}6^{\circ} 49^{\prime} 54.1^{\prime \prime} \mathrm{S} \\
34^{\circ} 55^{\prime} 26.9^{\prime \prime} \mathrm{O}\end{array}$ \\
\hline Ponto 7 & $\begin{array}{l}\text { Ipê Amarelo - } \\
\text { Tabebuia sp. }\end{array}$ & $\begin{array}{l}\text { Falar sobre as características da espécie e sobre as espécies } \\
\text { representantes de remanescente da Floresta Atântica. }\end{array}$ & $\begin{array}{l}6^{\circ} 50^{\prime} 17.82^{\prime \prime} \mathrm{S} \\
34^{\circ} 55^{\prime} 20.87^{\prime \prime} \mathrm{O}\end{array}$ \\
\hline Ponto 8 & $\begin{array}{l}\text { Cajueiro bravo - } \\
\text { Curatella. americana }\end{array}$ & $\begin{array}{l}\text { Falar sobre as características e peculiaridades da espécie, assim como } \\
\text { sua importância econômica e cultural. }\end{array}$ & $\begin{array}{l}6^{\circ} 54^{\prime} 56.3^{\prime \prime} \mathrm{S} \\
34^{\circ} 54^{\prime} 56.3^{\prime \prime} \mathrm{O}\end{array}$ \\
\hline Ponto 9 & $\begin{array}{l}\text { Praia do Oiteiro - } \\
\text { Ponto final }\end{array}$ & $\begin{array}{l}\text { Realizar uma síntese de tudo que foi explorado no percurso da trilha, } \\
\text { buscando sensibilizar e conscientizar os visitantes a respeito da } \\
\text { importância de uma unidade de conservação. }\end{array}$ & $\begin{array}{l}6^{\circ} 50^{\prime} 00.5^{\prime \prime} \mathrm{S} \\
34^{\circ} 54^{\prime} 38.1^{\prime \prime} \mathrm{O}\end{array}$ \\
\hline
\end{tabular}

Table 1. Points of attraction and respective approaches

\begin{tabular}{|c|c|c|c|}
\hline \multicolumn{2}{|c|}{ Points in the trail } & \multirow{2}{*}{$\begin{array}{l}\text { Aspects to be discussed } \\
\text { Present the recommendations to do the trail such as: keep quiet, be } \\
\text { careful when handling food, do not feed the animals, do not collect } \\
\text { any plant and/ or its inflorescence, do not litter and change anything; } \\
\text { encourage observation and environmental interpretation. }\end{array}$} & \multirow{2}{*}{$\begin{array}{l}\text { Coordinates } \\
6^{\circ} 49^{\prime} 55.4^{\prime \prime} \mathrm{S} \\
34^{\circ} 54^{\prime} 46.3^{\prime \prime} \mathrm{O}\end{array}$} \\
\hline Point 1 & The trailhead & & \\
\hline Point 2 & $\begin{array}{c}\text { Dendê - Elaeis } \\
\text { guineensis (invasive } \\
\text { specie) }\end{array}$ & $\begin{array}{l}\text { Present native and the opportunistic species predominant along the trail, } \\
\text { identifying their importance and the impact of the invasive species. }\end{array}$ & $\begin{array}{l}6^{\circ} 49^{\prime} 55.9^{\prime \prime} \mathrm{S} \\
34^{\circ} 54^{\prime \prime} 50.7^{\prime \prime O}\end{array}$ \\
\hline Point 3 & $\begin{array}{l}\text { Cajá - Spondias } \\
\text { mombin L. }\end{array}$ & $\begin{array}{l}\text { Talk about the characteristics and peculiarities of the species, as well as } \\
\text { its economic and cultural importance. }\end{array}$ & $\begin{array}{l}6^{\circ} 49^{\prime} 56.0^{\prime \prime} \mathrm{S} \\
34^{\circ} 55^{\prime} 00.3^{\prime \prime O}\end{array}$ \\
\hline Point 4 & Stream Caracabú & Refer the ecological importance of aquatic ecosystems. & $\begin{array}{l}6^{\circ} 49^{\prime} 56.1^{\prime \prime} \mathrm{S} \\
34^{\circ} 55^{\prime} 01.9^{\prime \prime} \mathrm{O}\end{array}$ \\
\hline Point 5 & $\begin{array}{l}\text { Cupiúba - Tapirira } \\
\text { guianensis }\end{array}$ & $\begin{array}{l}\text { Talk about the characteristics and peculiarities of the species, as well as } \\
\text { its ecological importance. }\end{array}$ & $\begin{array}{l}6^{\circ} 49^{\prime} 52.2^{\prime \prime S} \\
34^{\circ} 55^{\prime} 16.9^{\prime \prime O}\end{array}$ \\
\hline Point 6 & Stretch the cane Field & Warn of the impacts of the cultivation of sugar cane (climate and biota). & $\begin{array}{l}6^{\circ} 49^{\prime} 54.1^{\prime \prime} \mathrm{S} \\
34^{\circ} 55^{\prime} 26.9^{\prime \prime O}\end{array}$ \\
\hline Point 7 & $\begin{array}{l}\text { Ipê Amarelo - } \\
\text { Tabebuia sp. }\end{array}$ & $\begin{array}{l}\text { Talk about the characteristics of the species and the remaining species of } \\
\text { the Atlantic Rainforest. }\end{array}$ & $\begin{array}{l}6^{\circ} 50^{\prime} 17.82^{\prime \prime S} \\
34^{\circ} 55^{\prime} 20.87^{\prime \prime O}\end{array}$ \\
\hline Point 8 & $\begin{array}{l}\text { Cajueiro bravo - } \\
\text { Curatella. Americana }\end{array}$ & $\begin{array}{l}\text { Talk about the characteristics and peculiarities of the species, as well as } \\
\text { its economic and cultural importance. }\end{array}$ & $\begin{array}{l}6^{\circ} 54^{\prime} 56.3^{\prime \prime S} \\
34^{\circ} 54^{\prime} 56.3^{\prime \prime O}\end{array}$ \\
\hline Point 9 & $\begin{array}{l}\text { Oiteiro beach - } \\
\text { end of the trail }\end{array}$ & $\begin{array}{l}\text { Give an overview of all that has been explored; raise awareness of the } \\
\text { importance of the conservation unit. }\end{array}$ & $\begin{array}{l}6^{\circ} 50^{\prime} 00.5^{\prime \prime S} \\
34^{\circ} 54^{\prime} 38.1^{\prime \prime O}\end{array}$ \\
\hline
\end{tabular}




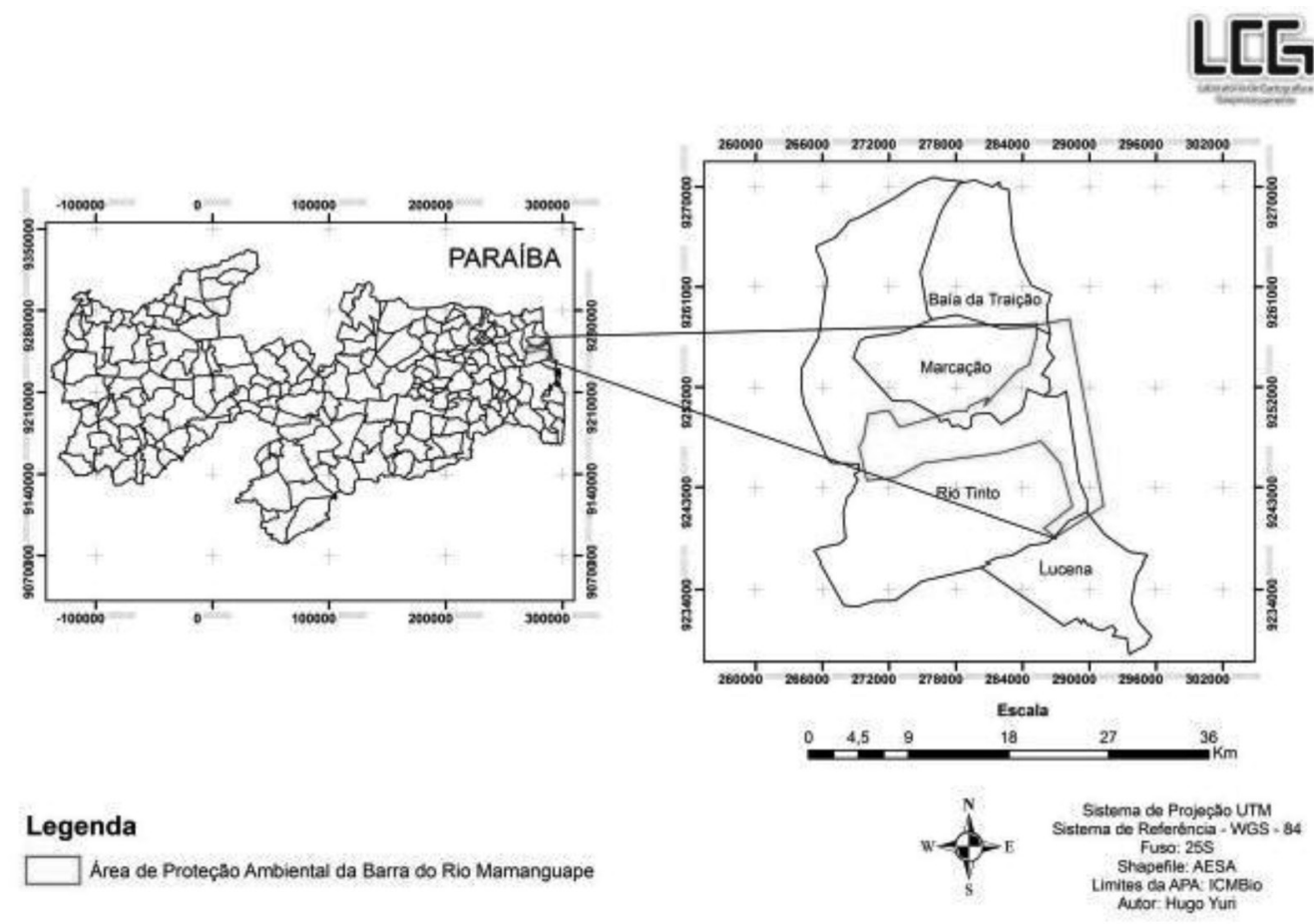

Figure 1. APA of Barra do Rio Mamanguape.

Source: Assis, 2014.

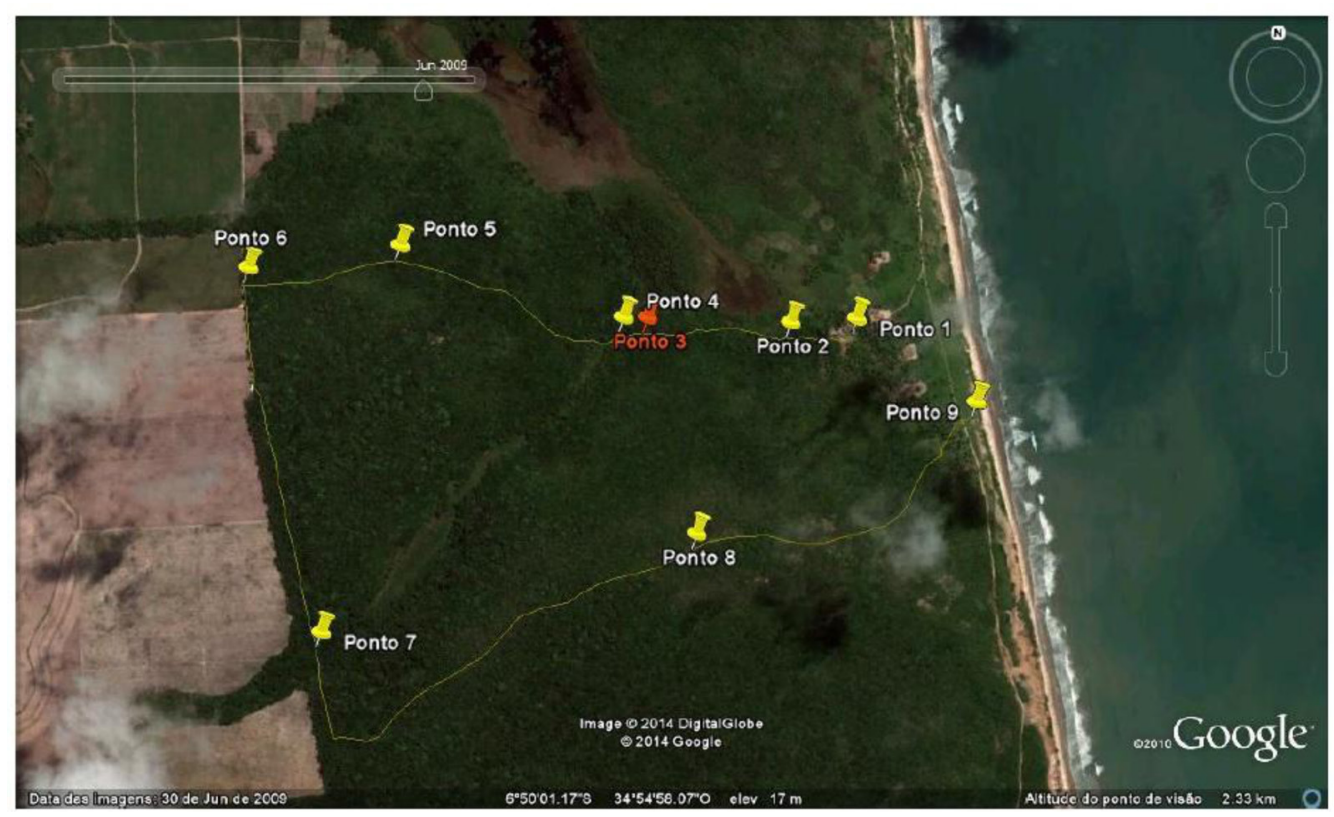

Figure 2. Points of Interpretative Trail in Forest of Oiteiro (points 1-9). 


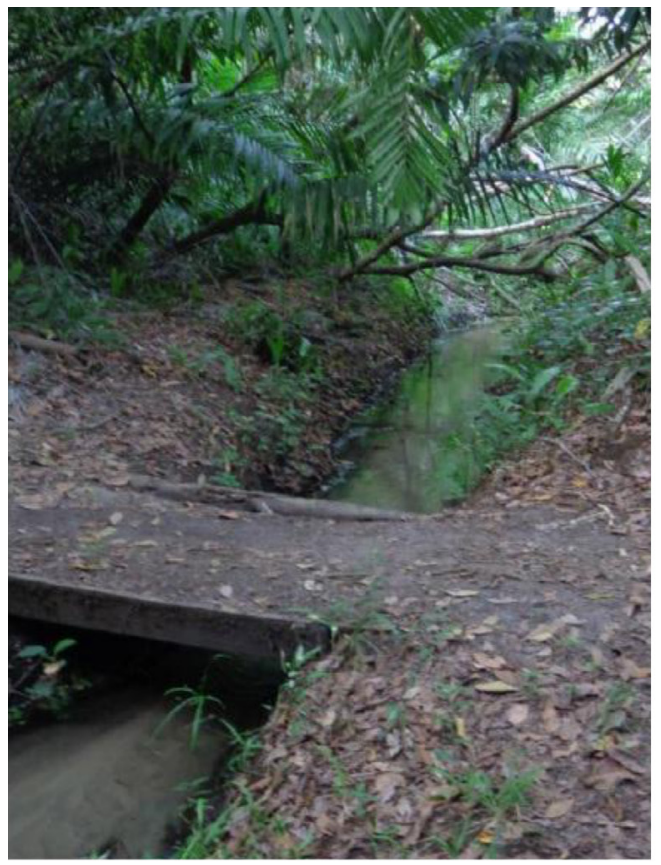

Figure 3. Caracabú creek

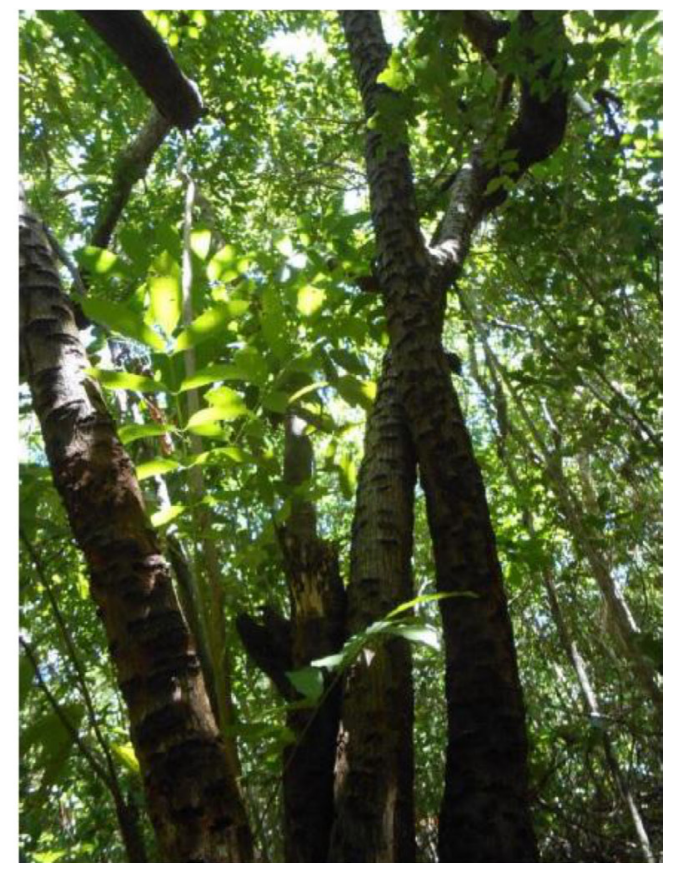

Figure 4. Cupiúba.

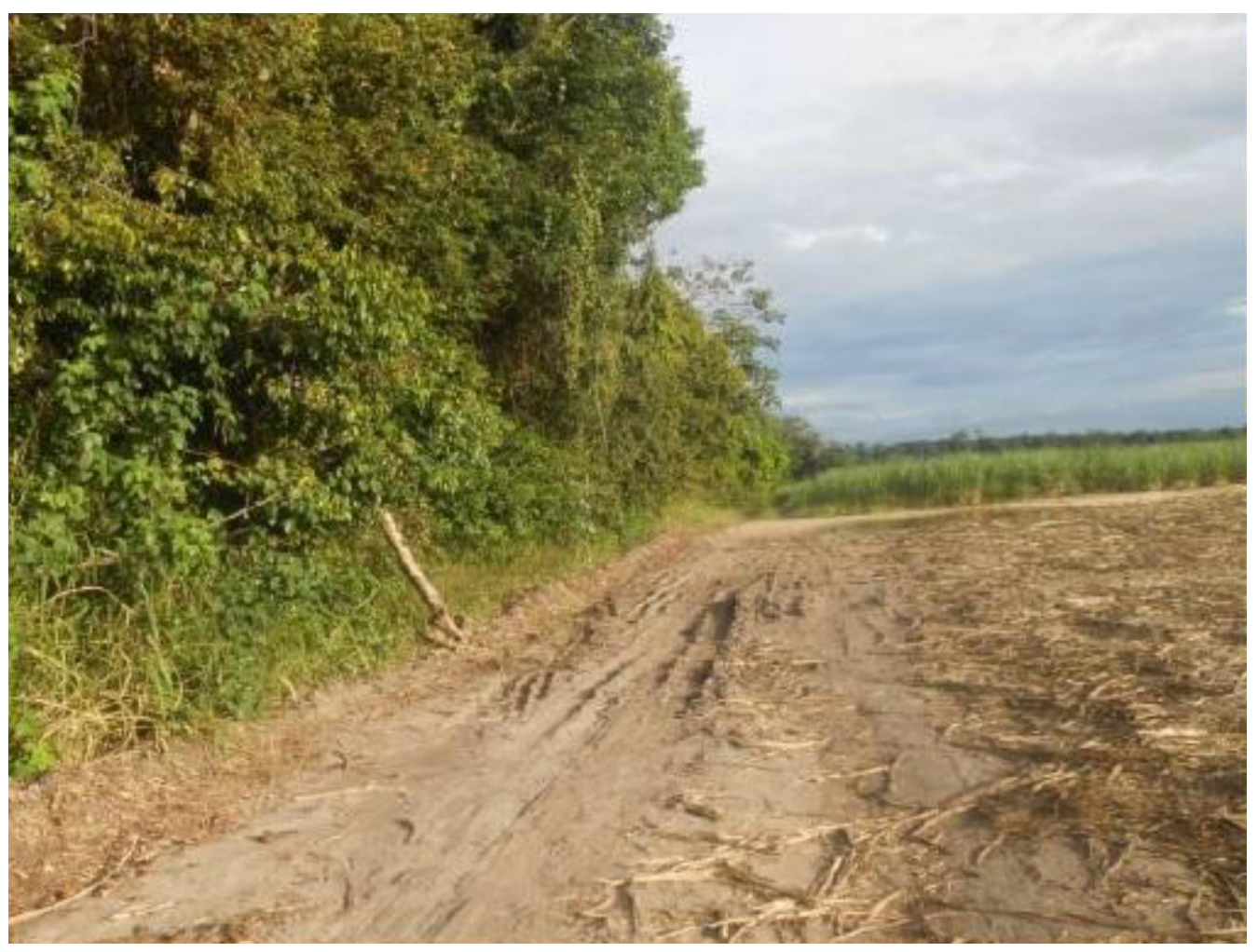

Figure 5. Point 6: The sugarcane plantation. 


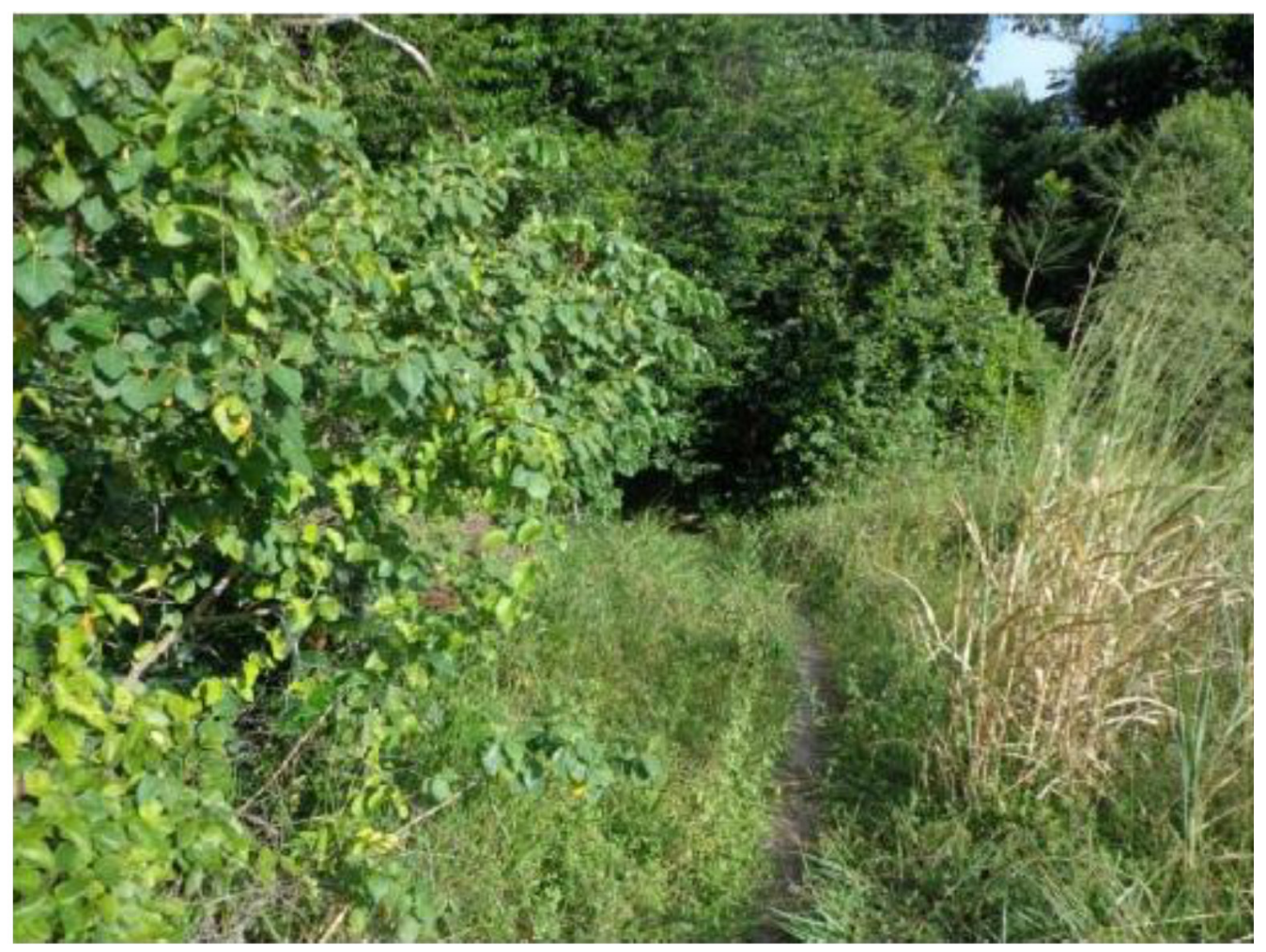

Figure 6. Return to the forest across the tableland.

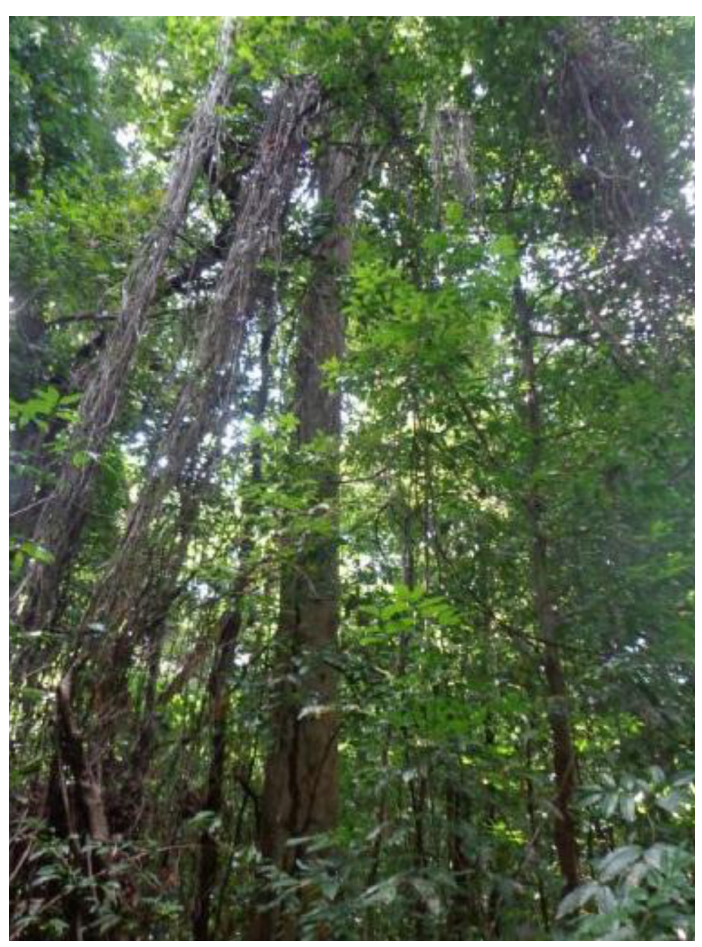

Figure 7, Ipê-amarelo. 


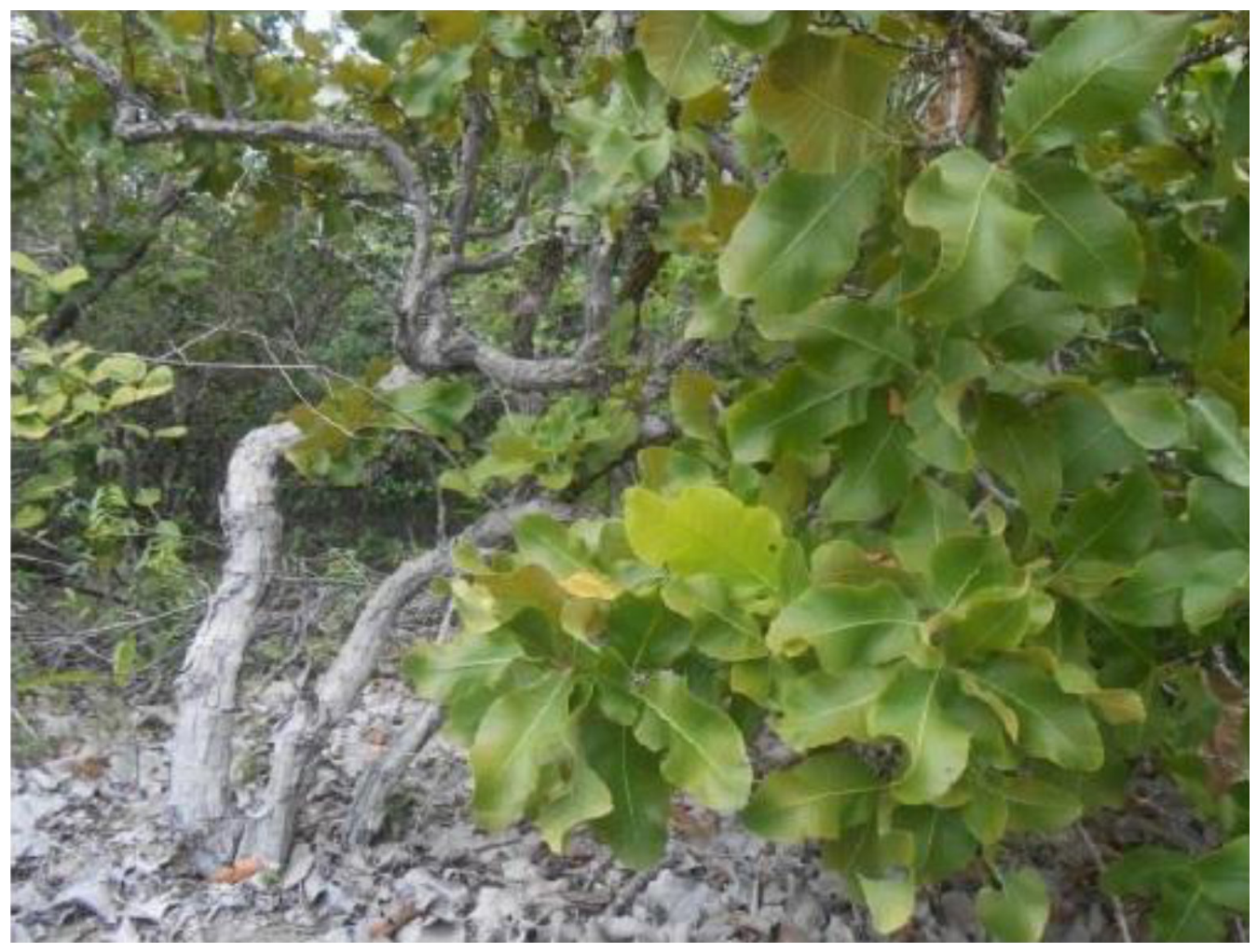

Figure 9. Oiteiro beach.

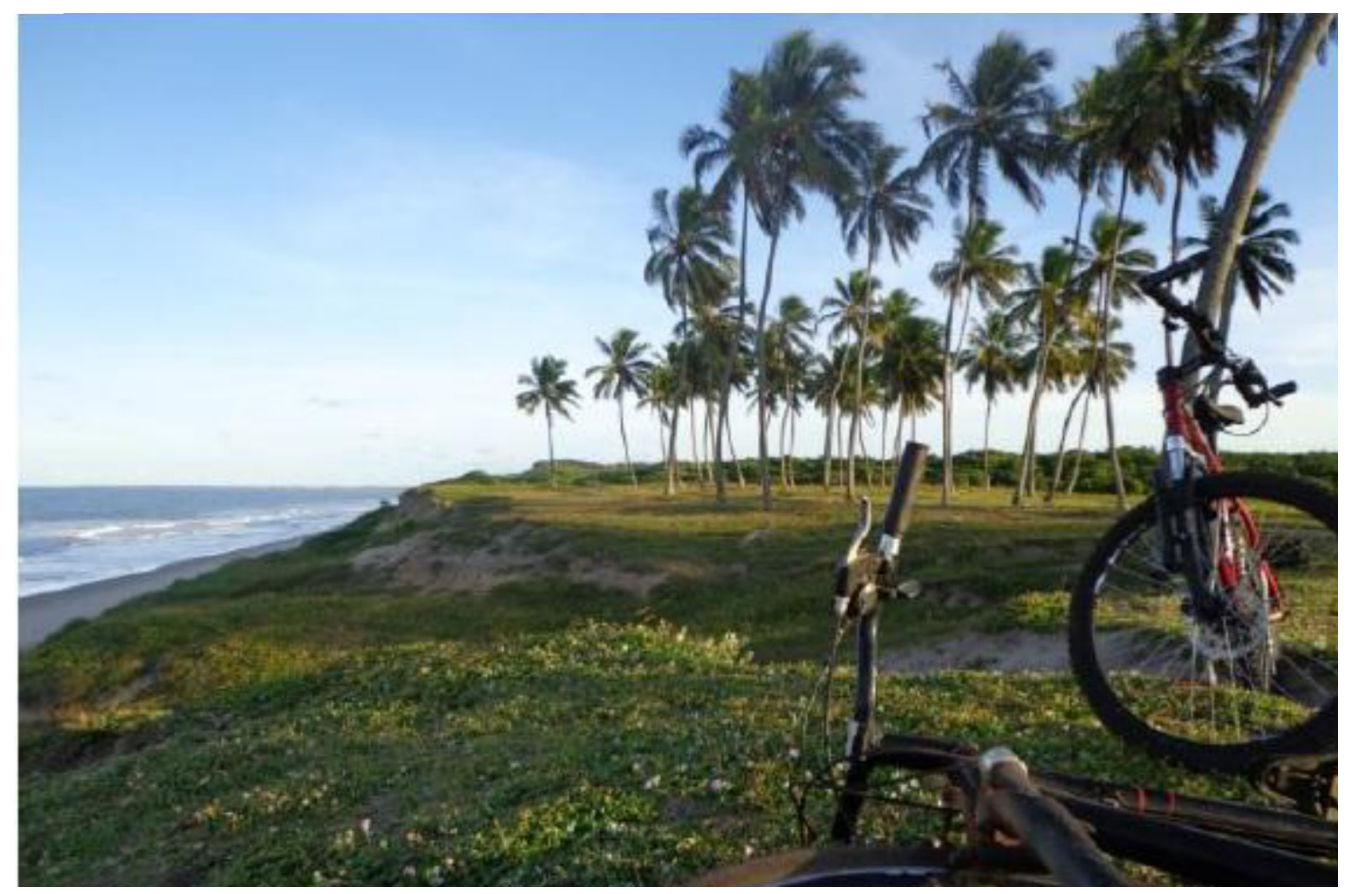

Figure 8. Cajueiro-bravo. 